\title{
A time saving tandem method for grinding dried forage samples to a small particle size
}

\author{
N.H. SUTTILL AND G.L. LEES
}

\begin{abstract}
A tandem arrangement of 2 grinding mills was devised to decrease the time required in grinding dried forage herbage to the uniform small particle size suitable for near infrared analysis. The grinding time was reduced to $38 \%$ and $40 \%$ for dried alfalfa and barley herbage respectively over the two-step method used previously.

Uniform small particle size is essential for accurate near infrared (NIR) analysis of forage samples (Winch and Major 1981). Our laboratory has previously used a two-step method where dried herbage samples are first ground through a Thomas Wiley model Ed-5 mill followed by a final processing with a Tecator 'Cyclotec' model 1093 grinding mill. The Cyclotec grinding mill and other mills with a 1-mm screen will give the desired result when used alone, but the process is very time-consuming since the low capacity and slow feeding rate for large samples ( $50 \mathrm{~g}$ or more) is restrictive and the collector bottle is small. The separate preliminary grinding step with the particle size screen in a Wiley mill does not give the uniformity of particle size required, but is used to allow the sample to be put through the Cyclotec more quickly. This does, however, add extra time for grinding, collecting, and transferring ground samples from one mill to another. The tandem arrangement reported here eliminates the two-step process and the final grindings are dispensed into a large bottle which can be labelled and stored.
\end{abstract}

\section{Procedure}

To connect the 2 mills, an adapter was made using a $76 \mathrm{~mm}$ diameter plastic bottle with a $19 \mathrm{~mm}$ I.D. neck $(500 \mathrm{~mL}$ chemical buffer solution container). The plastic bottle was cut in two and the wide opening of the half with the neck placed over the outlet of the Wiley mill as an adapter (Fig. 1). An $80 \mathrm{~cm}$ length of $19 \mathrm{~mm}$ I.D. latex tubing was secured over the neck opening of the plastic adapter. The free end of the tubing was pushed into a $22 \mathrm{~mm}$ hole cut in the side of a $67 \mathrm{~mm}$ plastic cup (bottom half of a $250 \mathrm{~mL}$ Tri-Pour plastic disposable breaker) fitted onto the intake port of the Cyclotec mill (Fig. 1). The Cyclotec mill was modified to allow $250 \mathrm{~mL}$ screw cap sample jars to be used as collector bottles by cutting a $33 \mathrm{~mm}$ hole into a plastic screw cap so the existing drop tube would fit into it snugly (Fig. 1). The plastic screw cap and drop tube were bonded together with contact cement.

To use the tandem mill arrangement, a $250 \mathrm{~mL}$ sample jar is screwed onto the cap connected to the Cyclotec drop tube. The 2 mills are switched on and the sample fed into the Wiley mill intake port. After grinding, the Wiley mill is shut off, the adapter and tubing removed from it, and any remaining sample in the adapter shaken down the tubing. The Cyclotec is then switched off, and the sample jar removed, labelled, and stored. Cleaning the system between samples is accomplished by first vacuuming the Wiley mill, replacing the adapter and tube, switching on both units, and vacuuming the outlet of the Cyclotec mill.

\footnotetext{
Authors are research scientists, Agriculture Canada Research Station Saskatoon, 107 Science Cres., Saskatoon, Saskatchewan. S7N 0X2.

This is Contribution No. 1016 of Agriculture Canada, Research Station, 107 Science Cres., Saskatoon, Saskatchewan. S7N $0 X 2$.
}

Manuscript accepted 8 March 1990.

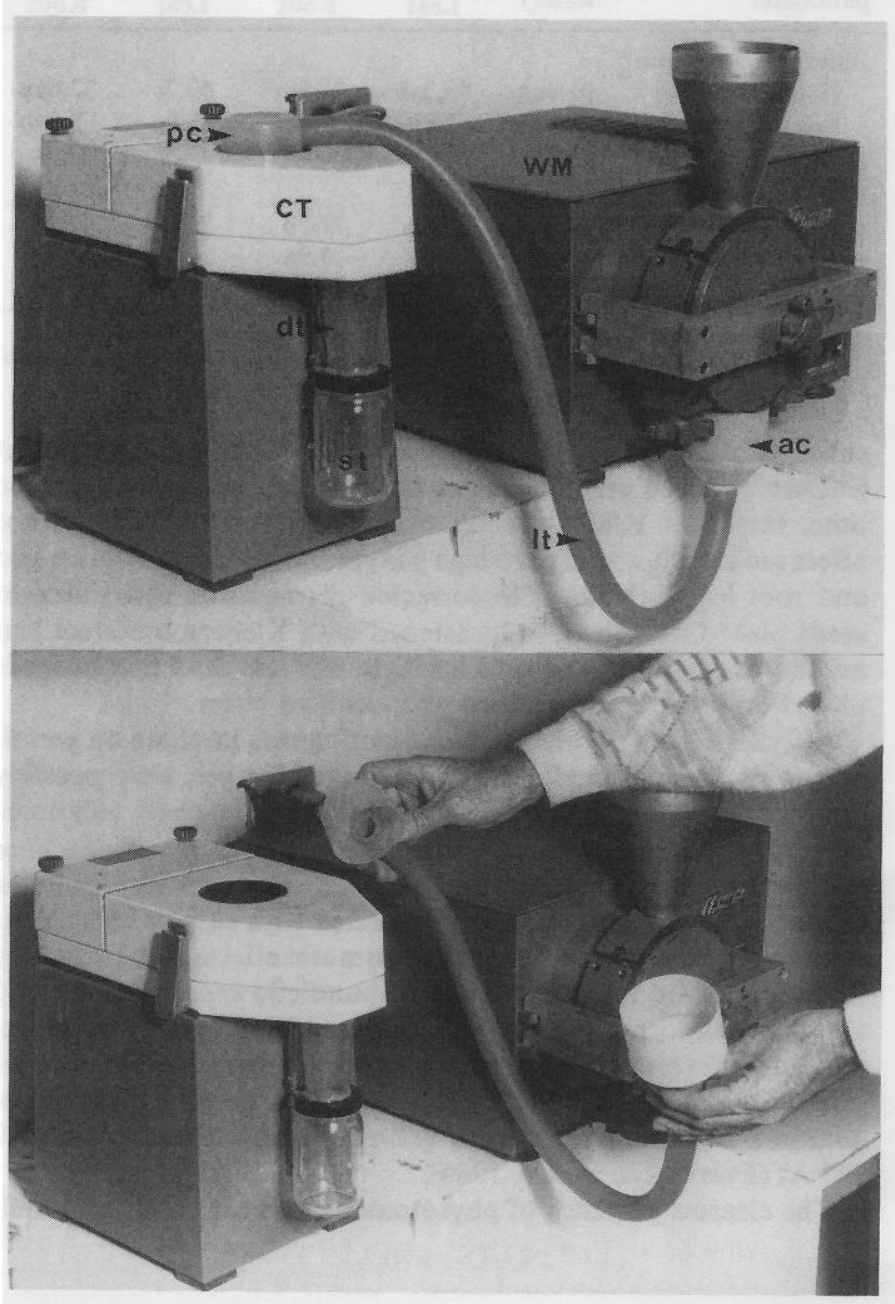

\section{Discussion}

The tandem arrangement of the Wiley and Cyclotec mills, both having 1-mm particle size screens, speeds up the process by taking the sample directly through both grinding steps with 1 throughput. The vacuum effect of the Cyclotec draws the ground sample directly from the Wiley mill, regrinds, and drops it into the sample jar screwed onto the drop tube. This eliminates the time used in collecting the grindings in a sample bottle from the Wiley mill, slowly adding the ground sample to the Cyclotec, and collecting the grindings in a small collector bottle (sometimes twice) and tansferring them to a storage bottle. The Wiley mill, even though it has the correct size screen, produces a more variable particle size distribution in the ground material due to the method of forcing the sample through the screen. This can cause variability in NIR analysis (unpublished data from our laboratory). The action of the Cyclotec gives the desired uniform size distribution, and because the sample is preground, uses less time in the process. Another 
Table 1. Grinding time (min) required for the old two-step grinding and the new tandem mill arrangement.

\begin{tabular}{lccccc}
\hline $\begin{array}{l}\text { Material } \\
\text { used }\end{array}$ & Method & $\begin{array}{c}\text { Number } \\
\text { samples }\end{array}$ & $\begin{array}{c}\text { Total } \\
\text { time }\end{array}$ & $\begin{array}{c}\text { Time/ } \\
\text { sample }\end{array}$ & $\begin{array}{c}\text { \% Time } \\
\text { saved }\end{array}$ \\
\hline $\begin{array}{l}\text { Dried } \\
\text { alfalfa }\end{array}$ & 2-step & 20 & 84 & 4.2 & \\
herbage & tandem & 20 & 52 & 2.6 & $38 \%$ \\
$\begin{array}{l}\text { Dried } \\
\text { barley }\end{array}$ & 2 -step & 20 & 83 & 4.2 & \\
herbage & tandem & 20 & 50 & 2.5 & $40 \%$ \\
\hline
\end{tabular}

Table 2. Projected savings using tandem grinding mills.

\begin{tabular}{lcccccc}
\hline \hline $\begin{array}{l}\text { Material } \\
\text { to be } \\
\text { ground }\end{array}$ & $\begin{array}{c}\text { \# Samples } \\
\text { to be } \\
\text { processed }\end{array}$ & $\begin{array}{c}\text { Method } \\
\text { used }\end{array}$ & $\begin{array}{c}\text { Time/ } \\
\text { sample } \\
\text { (min) }\end{array}$ & $\begin{array}{c}\text { Hours of } \\
\text { grinding } \\
\text { required }\end{array}$ & $\begin{array}{c}\text { Time } \\
\text { saved } \\
\text { (hrs) }\end{array}$ & $\begin{array}{c}\text { Wages } \\
\text { saved } \\
\text { (days) }\end{array}$ \\
\hline $\begin{array}{l}\text { Alfalfa } \\
\text { dried }\end{array}$ & 1000 & 2 -step & 4.2 & 70.0 & & \\
$\begin{array}{l}\text { herbage } \\
\begin{array}{l}\text { Barley } \\
\text { dried }\end{array}\end{array}$ & 1000 & tandem & 2.6 & 43.3 & 26.7 & $3.6 *$ \\
herbage & 8000 & 2-step & 4.2 & 560.0 & & \\
\hline
\end{tabular}

*Based on a 7.5 hour working day advantage of the tandem system is that the vacuum action of the Cyclotec is more effective in removing material from the grinding area of the Wiley mill which reduces cleaning time.

The modification shown here is an inexpensive and easy method to substantially reduce the time required to grind dried monocot and dicot herbage samples. Table 1 shows time comparisons in grinding dried alfalfa and barley leaves and stems using both the old two-step and the tandem system. Grinding time was reduced by $38 \%$ and $40 \%$ respectively when grinding dried alfalfa and barley herbage. Since we are routinely grinding dried forage samples each year, this will amount to considerable savings in the time required for technical help. Table 2 shows that when using the new tandem system, the grinding time required for 1,000 samples of alfalfa or barley will be reduced by 27 hours.

\section{Literature Cited}

Winch, J.E., and H. Major. 1981. Predicting nitrogen and digestibility of forages using near infrared reflectance photometry. Can. J. Plant Sci. 61:45-51. 